\title{
Mengembangkan keterampilan berpikir kritis dengan game ritual tumpe
}

\author{
Muliati Supandi *, Senam Senam \\ Universitas Negeri Yogyakarta Jalan Colombo No. 1, Karangmalang, Yogyakarta 55281, Indonesia. \\ *Corresponding Author. E-mail: muliasmantil@gmail.com \\ Received: 5 July 2019; Revised: 23 July 2019; Accepted: 12 August 2019
}

\begin{abstract}
Abstrak
Tujuan penelitian ini mengembangkan produk berupa game ritual tumpe untuk peserta didik SMP Kelas VII. Penelitian menggunakan metode research and developement (R \& D) yang dikembangkan oleh Thiagarajan. Penelitian mengacu pada model 4D: define (mendefinisikan), design (mendesain), develop (mengembangkan) dan disseminate (menyebarluaskan). Hasil penelitian menunjukkan bahwa media pembelajaran yang dikembangkan valid atau memenuhi kriteria kelayakan. Kategori kelayakan yang diperoleh dari ahli media dan juga guru dinilai sangat valid. Implementasi media pembelajaran di dalam kelas dapat meningkatkan partisipasi aktif peserta didik sehingga berdampak pada peningkatan kemampuan berpikir kritis. Jenis penelitian merupakan quasi eksperimen, menggunakan kelas kontrol dan kelas eksperimen. Gain score yang diperoleh pada saat pretest dan posttes pada kelas eksperimen menunjukkan perbedaan yang signifikan. Nilai gain score kelas eksperimen diperoleh 0,67 dan kelas kontrol 0,54 dengan kategori sedang. Efektivitas pembelajaran dilakukan dengan uji Manova diperoleh nilai sig. sebesar $0.000(<0.05)$. Kondisi tersebut menunjukkan bahwa media yang dikembangkan valid, praktis dan efektif digunakan dalam proses pembelajaran IPA di kelas VII SMP.
\end{abstract}

Kata Kunci: media pembelajaran; IPA; ritual tumpe; berpikir kritis

\section{Develop critical thinking skills with tumpe ritual games}

\begin{abstract}
The aim of this study was to develop product in the form of a tumpe ritual game for class VII junior high school students. The research used the research and developement $(R \& D)$ method developed by Thiagarajan. The research refers to the $4 D$ model: define, design, develop and disseminate. The result of the study indicates that learning media developed is valid or meet the eligibility criteria. The feasibility category obtained from media experts and also the teacher is highly valid. The implementation of learning media in the classroom can increase students' active participation so that it has an impact on improving critical thinking skill. This type of research uses quasi-experimental, using the control class and the experimental class. Gain scores obtained at the pre-test and post-test in the experimental class showed significant differences. The gain score of experimental class was 0.67 and the control class was 0.54 with the medium category. The effectiveness of learning was done by Manova test with the acquisition of sig values. amounting to 0,000 (<0.05). These condition indicated that the media developed was valid, practical and effective to be used in the process of learning science in class VII SMP.
\end{abstract}

Keywords: learning media; science; tumpe ritual; critical thingking.

How to Cite: Supandi, M., \& Senam, S. (2019). Mengembangkan keterampilan berpikir kritis dengan game ritual tumpe. Jurnal Inovasi Pendidikan IPA, 5(2), 139-146. doi:https://doi.org/10.21831/jipi.v5i2.25920

doi https://doi.org/10.21831/jipi.v5i2.25920

\section{PENDAHULUAN}

Kemampuan berpikir kritis diidentifikasi sebagai keterampilan hidup yang penting pada setiap individu (Maddux, Adam, \& Galinsky, 2010). Keterampilan berpikir kritis pada manusia berperan penting dalam menganalisis masalah, argumen, pemikiran dengan teliti berdasarkan informasi dan kredibilitas sumber data; berusaha memberikan penilaian terhadap masalah, pemikiran dengan benar; mampu memecahkan permasalahan dengan logis dalam berbagai situasi dan membuat keputusan berdasarkan pertimbangan, fakta dan bukti yang relevan. Pada proses pembelajaran, kemampuan berpikir peserta didik dapat dikembangkan dengan memperkaya pengalaman yang bermakna melalui pemecahan masalah di dalam kelas. 


\section{Jurnal Inovasi Pendidikan IPA, 5 (2), 2019 - 140}

Muliati Supandi, Senam Senam

Saat ini, kemampuan berpikir kritis peserta didik di Sulawesi Tengah masih terbilang rendah. Berdasarkan rata-rata ujian nasional (UN) peserta didik sekolah menengah pertama (SMP), provinsi Sulawesi Tengah secara nasional dapat dikatakan masih rendah yaitu 51,00 pada tahun ajaran 2017/2018 dan 47,21 pada tahun 2018/2019. Jika ditinjau dari peringkat, Provinsi Sulawesi Tengah berada pada peringkat 25 tahun 2017/2018 dan 26 pada tahun ajaran 2018/2019 dari 34 provinsi di Indonesia (Pusat Penelitian Pendidikan Kementerian Pendidikan dan Kebudayaan Republik Indonesia, 2019).

Permasalahan rendahnya kemampuan berpikir kritis di Sulawesi Tengah, terjadi di SMP Negeri 1 Batui. Berdasarkan penelitian pendahuluan yang dilakukan di SMP Negeri 1 Batui diperoleh informasi dari hasil wawancara dan observasi bahwa pembelajaran IPA di kelas masih bersifat pasif, belum adanya keberanian peserta didik untuk bertanya dan mengungkapkan pendapat saat proses pembelajaran berlangsung. Hasil tes awal berpikir kritis kelas VII ${ }^{\mathrm{A}}$ dan $\mathrm{VII}^{\mathrm{D}}$ pada materi suhu dan kalor diperoleh nilai tes rata-rata di bawah 60 atau belum mencapai kriteria ketuntasan maksimal.

Salah satu faktor rendahnya kemampuan berpikir kritis peserta didik kelas VII SMP Negeri 1 Batui yaitu proses belajar mengajar yang dilakukan pendidik umumnya menggunakan metode inquiry, tetapi masih dibimbing secara penuh oleh pendidik. Pendidik belum memberikan kesempatan kepada peserta didik untuk belajar secara mandiri dan memecahkan persoalan sendiri. Pembelajaran yang dilakukan berpusat pada pendidik mengakibatkan peserta didik bergantung dalam menghadapi soal-soal yang menggunakan cara berpikir kritis. Proses pembelajaran IPA menjadi kurang menarik, monoton dan membosankan. Kondisi tersebut mengakibatkan tidak tercapainya tujuan pembelajaran yang diharapkan. Proses pembelajaran yang bersifat teacher-center membuat keterampilan berpikir peserta didik tidak terlatih dan merasa tidak tertarik serta mudah merasa bosan. Penggunaan media pembelajaran yang tepat sangat diperlukan agar peserta didik memiliki keinginan untuk terlibat aktif di dalam kelas. Ada banyak media yang dapat digunakan dalam pembelajaran IPA, salah satunya menggunakan media game.

Game merupakan suatu aktivitas yang menyenangkan, mengajak pemain untuk selalu berusaha menjadi pemenang dalam menyelesaikan permainan dan naik ke level yang lebih tinggi. Kemampuan dalam menyelesaikan suatu tantangan akan melatih kemampuan berpikir kritis seseorang. Kondisi tersebut memungkinkan pemain dalam melakukan aktivitas berpikir kritis dalam kondisi yang menyenangkan (Prasetyo, 2017).

Sistem pembelajaran menggunakan game dapat menjadikan pembelajaran IPA menarik, tidak monoton, dan memudahkan penyampaian pesan karena adanya gambar, suara, tulisan, serta animasi (Honiotes, 2011). Peserta didik dapat mempelajari materi secara mandiri dengan menggunakan komputer atau handphone yang dimiliki.

Game menawarkan lingkungan di mana peserta didik secara aktif tertarik dan dapat melanjutkan kegiatan mereka secara individu, serta peluang untuk belajar dengan melakukan. game digital telah digunakan sebagai alat yang efektif untuk memfasilitasi pembelajaran di berbagai domain seperti ilmu komputer, ilmu komunikasi, pembelajaran bahasa, teknik, kesehatan, dan pendidikan (Barzilai \& Blau, 2014; Chang, Lai, \& Hwang, 2018; Giannakos, 2013; Hao et al., 2010; Hong, Cheng, Hwang, Lee, \& Chang, 2009). Semua model dan teori yang dikembangkan di zaman kita menekankan pentingnya menggunakan teknologi pembelajaran dalam pendidikan dalam hal memberikan efek positif pada pembelajaran. Penting bagi individu dan masyarakat untuk mengubah diri mereka di zaman ketika informasi diubah dan diperbarui setiap saat.

Game dapat menjadi alat yang berharga untuk memperkaya pendidikan sains, karena dapat memfasilitasi sejumlah kondisi yang mendorong pembelajaran: motivasi peserta didik, pembelajaran aktif, adaptifitas, kolaborasi, dan simulasi. Selain itu, mereka memberikan instruktur kemampuan untuk mengumpulkan metrik pembelajaran dengan relatif mudah (Xiao \& Zhang, 2016).

Pemilihan game sebagai media pembelajaran didukung penelitian sebelumnya. (Chee, Tan, Tan, \& Jan, 2012; Cicchino, 2015) telah mengaplikasikan media game ke dalam proses pembelajaran. Hasil penelitian yang diperoleh penggunaan game memberikan pengaruh yang positif terhadap hasil belajar peserta didik. Hal serupa dilakukan (Bakan \& Bakan, 2018) dalam penelitian kepustakaan dan ditemukan bahwa permainan peserta didik, serta pemahaman kognitif dan aplikasi tingkat pengetahuan lapangan lebih efektif dalam pembelajaran dan prestasi peserta didik. (Vlachopoulos \& Makri, 2017) menjalaskan bahwa game atau simulasi memiliki dampak positif pada tujuan pembelajaran. Para 


\title{
Jurnal Inovasi Pendidikan IPA, 5 (2), 2019 - 141
}

\author{
Muliati Supandi, Senam Senam
}

peneliti dalam karyanya mengidentifikasi tiga hasil pembelajaran ketika mengintegrasikan Game ke dalam proses pembelajaran: kognitif, perilaku, dan afektif.

Chang et al. (2018) meneliti perbedaan pengalaman aliran antara pembelajaran berbasis game dan kelompok belajar non-game pada jenis beban kognitif intrinsik, relevan, dan asing. Seratus tiga peserta ditugaskan ke kelompok eksperimen (50 peserta didik) dan kelompok kontrol (53 peserta didik). Hasil penelitian menunjukkan bahwa kelompok belajar berbasis game memiliki pengalaman lebih banyak daripada aliran kelompok belajar non-game. Perbedaan lain adalah bahwa kelompok belajar berbasis permainan berbeda dari kelompok lain dalam hal kemampuan mereka untuk berkonsentrasi pada pembelajaran mereka sendiri serta kemampuan untuk mengendalikan.

Media game jika diimplementasikan dalam pembelajaran dapat meningkatkan pemahaman konsep dan keterampilan berpikir kritis yang dibutuhkan dalam menghadapi tantangan abad 21. Berpikir kritis bagian dari penalaran dan berpikir reflektif yang difokuskan dalam memutuskan apa yang diyakini dan akan dilakukan (Ennis, 1993). Game yang mengandung tujuan edukasi dipercaya berpotensi untuk menyampaikan materi akademis lebih learner-centered atau sebuah pembelajaran yang berpusat pada peserta didik, lebih mudah dan lebih menyenangkan.

Game sebagai media pembelajaran bukan merupakan suatu hal yang baru. (Gros, 2007) menginterpretasikan bahwa saat ini game telah banyak diadopsi sebagai media pendukung dalam mempermudah dan mengefisienkan proses pembelajaran. Beberapa tahun terakhir, game komputer edukasi telah mendapat perhatian yang meningkat dari para peneliti dan pendidik tetapi lebih sedikit dari industri game. Secara penyajian isi, game yang ada saat ini belum menyajikan pembelajaran secara kontekstual. (Rini, Tangkas, \& Said, 2014) menjelaskan bahwa penggunaan materi pembelajaran yang sesuai dengan karakteristik dan lingkungan belajar peserta didik merupakan salah satu kunci keberhasilan pembelajaran IPA.

Game akan lebih kontekstual apabila diintegrasikan dengan kearifan lokal daerah dimana peserta didik tinggal. Berdasarkan hasil penelitian (Suastra, 2009), latar belakang budaya yang dimiliki peserta didik dan dibawa ke dalam kelas selama proses pembelajaran berlangsung memainkan peran penting pada proses penguasaan materi. Latar belakang budaya yang dibawa guru dan peserta didik sangat menentukan dalam menciptakan atau pengkondisian proses belajar mengajar yang bermakna dan berkonteks. Pembelajaran yang tidak memfasilitasi peserta didik untuk menghubungkan dan melihat relevansinya dengan lingkungan kesehariannya cenderung mengakibatkan kurangnya partisipasi, dan kesulitan mencapai atau mempertahankan informasi yang disajikan (Anderson \& Pellicer, 1998; Campbell \& Harris, 2001; Hootstein, 1994; Wood \& Jones, 1994).

Batui, Kabupaten Banggai provinsi Sulawesi Tengah memiliki sebuah kearifan lokal yang dinamakan dengan ritual tumpe. Ritual tumpe merupakan sebuah upacara adat tahunan yang sering diadakan oleh masyakat Batui sebagai wujud bakti kepada nenek moyang mereka. Ritual tumpe sendiri sebuah ritual pengantaran telur burung Maleo kepada kerajaan banggai yang meliputi proses mengumpulkan, mendoakan, mengantarkan, dan monsawe tumpe yang menjadi penutup dari ritual tersebut.

Tahapan ritual tumpe yang dijalankan oleh masyarakat Batui dapat menjelaskan konsep suhu dan kalor yang ada dalam pembelajaran IPA di kelas VII SMP dengan kompetensi dasar 3.4 yaitu memahami konsep suhu, pemuaian, kalor, perpindahan kalor, dan penerapannya dalam kehidupan sehari-hari termasuk mekanisme menjaga kestabilan tubuh manusia dan hewan.

Latar belakang budaya peserta didik menjadi salah satu faktor pembatas bagi peserta didik untuk memahami konsep-konsep IPA di sekolah. Walaupun anak-anak bisa memahami sains secara umum, tetapi tidak sampai membumi. Berdasarkan penjelasan di atas, media pembelajaran berupa RPG Ritual Tumpe dapat efektif diimplementasikan dalam pembelajaran untuk meningkatkan kemampuan berpikir kritis peserta didik. Kebutuhan akan media pembelajaran yang terintegrasi kearifan lokal dinilai sangat perlu untuk dikembangkan untuk meningkatkan keterampilan berpikir kritis peserta didik SMP.

\section{METODE}

Metode penelitian yang digunakan merupakan research and developement $(\mathrm{R} \& \mathrm{D})$ model 4D (Thiagarajan, Semmel, \& Semmel, 1974). Model 4D terdiri dari 4 tahap, mendefinisikan, mendesain, mengembangkan dan menyebarluaskan.

Tahap mendefinisikan dan mendesain menghasilkan draft media pembelajaran berupa game ritual tumpe yang dapat dikembangkan melalui tahapan evaluasi dan pengujian. Tahap 
pengembangan diprakarsai oleh penilaian para ahli. Seorang ahli dalam IPA dan seorang ahli dalam pembelajaran berbasis komputer. Evaluasi juga dilakukan oleh dua orang guru IPA. Hasil evaluasi dari para ahli dan guru IPA menjadi pertimbangan untuk revisi produk pengembangan.

Setelah penilaian para ahli dan evaluasi dari para guru IPA, produk yang dikembangkan diuji oleh peserta didik. Pengujian pendahuluan dilakukan untuk kelompok yang lebih kecil terdiri dari 9 peserta didik. Respon peserta didik dalam uji coba sekala kecil digunakan sebagai pertimbangan untuk perbaikan media pembelajaran yang dikembangkan. Setelah beberapa revisi, produk yang dikembangkan diuji pada kelompok yang lebih besar yang terdiri dari 60 peserta didik SMP. Penelitian menggunakan satu kelompok eksperimen dan kontrol pretest dan posttest dalam pengujian lapangan. Hasil dari pengujian lapangan dalam kelompok peserta didik yang lebih besar, peserta didik memberikan respon terhadap program komputer yang mereka gunakan. Tanggapan digunakan sebagai pertimbangan untuk revisi akhir.

Kualitas game ritual tumpe yang dikembangkan ditentukan melalui penilaian para ahli, evaluasi guru dan respon peserta didik. Instrumen yang digunakan untuk mengumpulkan para ahli penilaian, evaluasi guru dan tanggapan peserta didik adalah kuesioner. Kuesioner yang dikembangkan dengan menggunakan skala likert (1-4). Kuesioner untuk evaluasi oleh para ahli materi mencakup lima aspek, yaitu kebenaran, keluasan dan kedalaman konsep, kebahasaan, kemanfaatan, dan keterlaksanaan. Kuesioner untuk evaluasi oleh ahli media pembelajaran mencakup tiga aspek, yaitu kemudahan, kebahasaan, kemenarikan.

Kuesioner untuk evaluasi oleh guru IPA mencakup tujuh aspek, yaitu kesesuaian/relevansi, kebenaran, kebahasaan, kemanfaatan, keterlaksanaan, kemudahan dan kemenarikan. Tanggapan para peserta didik dikumpulkan melalui instrumen dengan skala likert 1-4. Instrumen berisi beberapa pernyataan yang benar-benar mengumpulkan respon peserta didik tentang kebahasaan, kemaanfaatan, kemudahan dan kemenarikan.

Instrumen untuk mengukur efektivitas produk pembelajaran dalam mempelajari IPA adalah soal essay berpikir kritis yang terdiri atas 10 butir soal yang diberikan pada pretest dan posttest sebelum dan sesudah menggunakan produk pengembangan.

Penelitian menggunakan teknik deskriptif dalam analisis data. Skor evaluasi media pembelajaran yang diberikan oleh para ahli dan guru IPA melalui kuesioner dirata-rata. Skor rata-rata dari setiap aspek diklasifikasikan ke dalam tingkat kesesuaian berdasarkan kriteria pada Tabel 1. (Sukardi, 2009) membuat klasifikasi dengan perbandingan dengan skor rata-rata ideal (Xi) dan standar ideal skor deviasi (SDi) sebagai dasar. Tingkat kualifikasi dibagi menjadi empat kategori dengan kriteria seperti pada Tabel 1.

Tabel 1. Kriteria validasi

\begin{tabular}{cc}
\hline Skor Rerata & Kriteria Validasi \\
\hline $4,00-3,75$ & Sangat Valid \\
$3,75-3,00$ & Valid \\
$3,00-2,25$ & Kurang \\
$2,25-1,50$ & Sangat Kurang Valid \\
\hline
\end{tabular}

(Sukardi, 2009)

Peningkatan berpikir kritis diukur berdasarkan pengkategorian menurut (Hake, 1997). Gain score yang diperoleh pada pretest maupun posttest pada kelas kontrol maupun kelas eksperimen seperti pada Tabel 2. Setelah diperoleh hasil gain score maka data diuji secara Manova untuk melihat pengaruh yang diakibatkan oleh produk pengembangan.

Tabel 2. Kriteria Gain Score (Hake, 1999)

\begin{tabular}{cc}
\hline Skor Rerata & Gain Score \\
\hline$>0,7$ & Tinggi \\
$0,3-0,7$ & Sedang \\
$<0,3$ & Rendah \\
\hline
\end{tabular}

\section{HASIL DAN PEMBAHASAN}

Game ritual tumpe merupakan produk yang dikemas menggunakan aplikasi RPG Maker $M V$, didukung dengan Coreldraw, paintool SAI dan PISKEL. Produk pengembangan dimainkan secara individu dan pengguna dapat memilih karakter sesuai tokoh yang dibuat. Game diintegrasikan dengan kearifan lokal ritual tumpe memiliki dampak positif dalam melatih peserta didik untuk pemecahan masalah, mengkoordinasi untuk mencari tahu dan berimajinasi, menumbuhkan motivasi, berkompetisi serta motivasi mempelajari isu dan persoalan.

Inovasi penelitian ini yaitu media game mengintegrasikan kearifan lokal ritual tumpe yang dikemas sesuai tahapan ritual tumpe. Game menggambarkan kehidupan keseharian, sesuai kondisi lingkungan peserta didik. Pada penelitian game terdahulu lebih sekedar mengembangkan game edukasi tanpa mempertimbangkan kondisi ataupun lingkungan tempat peserta didik.

Game ritual tumpe yang dikembangkan 
untuk pembelajaran IPA dalam penelitian ini dinilai valid. Game yang dikembangkan memperoleh rata-rata 3,43 (sangat valid) oleh ahli materi dan 3,58 (sangat valid) oleh ahli media seperti pada Tabel 3 dan 4 ..

Tabel 3. Hasil Penilaian Kelayakan Materi

\begin{tabular}{|c|c|c|c|}
\hline Aspek & $\begin{array}{c}\text { Skor } \\
\text { Rerata }\end{array}$ & $\%$ & Kategori \\
\hline Kebenaran & 3,70 & 92,50 & $\begin{array}{c}\text { Sangat } \\
\text { Valid }\end{array}$ \\
\hline $\begin{array}{l}\text { Keluasan dan } \\
\text { Kedalaman Konsep }\end{array}$ & 3,00 & 75,00 & Valid \\
\hline Kebahasaan & 4,00 & 100,00 & $\begin{array}{c}\text { Sangat } \\
\text { Valid }\end{array}$ \\
\hline Kemanfaatan & 3,00 & 75,00 & Valid \\
\hline Keterlaksanaan & 3,50 & 87,50 & $\begin{array}{c}\text { Sangat } \\
\text { Valid }\end{array}$ \\
\hline Rata-rata & 3,43 & 86,00 & $\begin{array}{c}\text { Sangat } \\
\text { Valid }\end{array}$ \\
\hline
\end{tabular}

Tabel 3 menunjukkan bahwa game pembelajaran IPA berbasis kearifan lokal yang dikembangkan sesuai dengan kompetensi inti, kompetensi dasar, indikator dan tujuan pembelajaran yang akan dicapai.

Setelah melalui tahap revisi, dilakukan penilaian terhadap game. Adapun hasil penilaian memberikan arahan hasil awal media ini yang dikembangkan memperoleh nilai 3,43 dengan kategori sangat baik. Berdasarkan penilaian tersebut, 5 aspek kelayakan materi sudah terpenuhi.
Tabel 4. Hasil Penilaian Kelayakan Media

\begin{tabular}{lccc}
\hline \multicolumn{1}{c}{ Aspek } & Skor & $\%$ & Kategori \\
\hline Kemudahan & 3,50 & 87,50 & Sangat Valid \\
Kebahasaan & 3,67 & 91,75 & Sangat Valid \\
Kemenarikan & 3,57 & 89,25 & Sangat Valid \\
Rata-rata & 3,58 & 89,50 & Sangat Valid \\
\hline
\end{tabular}

Berdasarkan Tabel 4 terlihat bahwa Game pembelajaran IPA berbasis kearifan lokal yang dikembangkan termasuk kategori sangat baik dengan rata-rata skor 3,58 dan persentase penilaian $89,50 \%$. Beberapa aspek yang belum terpenuhi diberi masukan/saran dari dosen ahli media.

Kepraktisan perangkat pembelajaran dalam penelitian ini dinilai berdasarkan kelayakan pembelajaran menggunakan produk pengembangan. Setelah dilakukan uji kepraktisan yang dilakukan oleh dua orang guru, produk yang dikembangkan perlu diukur keterbacaan oleh peserta didik dan diperoleh hasil seperti dalam Tabel 5.

Berdasarkan Tabel 6 dapat dianalisis bahwa skor pengamatan rata-rata untuk pelaksanaan pembelajaran pada uji coba lapangan adalah 3,24 dengan kategori baik. Berdasarkan kriteria yang ditetapkan, produk pengembangan termasuk dalam kriteria praktis, karena $\mathrm{Sr}$ berada di kisaran $2,5 \leq \mathrm{Sr}<3,5$ (Tabel 5). Data tentang tanggapan peserta didik diisi oleh sembilan peserta didik dalam uji coba terbatas.

Tabel 5. Respon Guru terhadap Kepraktisan game

\begin{tabular}{lccl}
\hline \multicolumn{1}{c}{ Aspek } & Skor Rerata & $\%$ & \multicolumn{1}{c}{ Kategori } \\
\hline Kesesuaian/relevansi & 4,00 & 100,00 & Sangat Baik \\
Kebenaran & 3,32 & 83,00 & Sangat Baik \\
Kebahasaan & 3,50 & 87,50 & Sangat Baik \\
Kemanfaatan & 3,67 & 91,75 & Sangat Baik \\
Keterlaksanaan & 3,57 & 89,25 & Sangat Baik \\
Kemudahan & 3,58 & 89,50 & Baik \\
Kemenarikan & 3,35 & 83,75 & Sangat Baik \\
Rata-rata & 3,59 & 89,25 & Sangat Baik \\
\hline
\end{tabular}

Tabel 6. Rekapitulasi Keterbacaan Game oleh Peserta Didik

\begin{tabular}{lccc}
\hline \multicolumn{1}{c}{ Aspek } & Rerata Skor & Persentase $(\%)$ & Kategori \\
\hline Kebahasaan & 3,35 & 83,75 & Sangat Baik \\
Kemanfaatan & 3,32 & 83,00 & Baik \\
Kemudahan & 3,10 & 77,50 & Baik \\
Kemenarikan & 3,22 & 80,50 & Baik \\
Rata-rata & 3,25 & 81,19 & Sangat Baik \\
\hline
\end{tabular}

Tabel 6. Hasil Analisis Berpikir Kritis

\begin{tabular}{lccccc}
\hline \multirow{2}{*}{ Komponen } & \multicolumn{2}{c}{ Kelas Eksperimen } & \multicolumn{2}{c}{ Kelas Kontrol } \\
\cline { 2 - 6 } & Pretest & Posttest & Pretest & Posttest \\
\hline Rata-rata nilai & 36,92 & 79,14 & 32,07 & 0,96 \\
Gain Score & \multicolumn{2}{c}{0,67} & \multicolumn{3}{c}{0,54} \\
Kategori & \multicolumn{2}{c}{ Sedang } & \multicolumn{3}{c}{ Sedang } \\
\hline
\end{tabular}


Pada saat uji coba terbatas terlihat bahwa skor rata-rata tanggapan peserta didik terhadap game yang dikembangkan dalam uji coba lapangan dalam kategori sangat baik. Hasil analisis respon peserta didik dari uji coba terbatas, game dinyatakan baik dalam semua aspek, baik aspek kebahasaan, kemanfaatan, kemudahan dan kemenarikan. Game yang dikembangkan layak digunakan sebagai media pembelajaran yang sesuai dengan kebutuhan peserta didik.

Implementasi media pembelajaran dalam skala luas, diperoleh peningkatan hasil belajar peserta didik setelah menggunakan media pembelajaran game ritual tumpe. Adapun Hasil perbedaan pretest dan posttest dapat disajikan dalam Tabel 6.

Rata-rata gain score keterampilan berpikir kritis peserta didik di SMP Negeri 1 Batui pada kelas eksperimen adalah 0,67 yang termasuk kategori sedang dan pada kelas kontrol adalah 0,54 yang termasuk kategori sedang.

Nilai gain score yang didapat kemudian dianalisis menggunakan uji Manova untuk membuktikan bahwa peningkatan penguasaan keterampilan berpikir kritis pada kelas eksperimen disebabkan oleh game pembelajaran IPA yang dikembangkan. Game yang dikembangkan mengintegrasikan kearifan lokal masyarakat sehingga peserta didik tertarik dan mudah memahaminya karena sesuai dengan konteks kehidupan sehari-hari. Hal ini sejalan dengan (Kearsley, 2010) yang mendefiniskan bahwa pembelajaran merupakan fungsi dari aktivitas, konteks dan budaya masyarakat setempat.

Tabel 7. Uji Manova

\begin{tabular}{llc}
\hline & Effect & Sig. \\
\hline Kelas & Pillai's Trace & 0,000 \\
& WiRPP 'Lambda & 0,000 \\
& Hotelling's Trace & 0,000 \\
Roy's Largest Root & 0,000 \\
\hline
\end{tabular}

Berdasarkan Tabel 7, keterampilan berpikir kritis memperoleh nilai sig sebesar 0,000. Apabila taraf signifikansi ditetapkan sebesar 0,05 , maka nilai sig yang diperoleh harus lebih kecil dari 0,05. Kondisi tersebut menjelaskan bahwa terdapat perbedaan berpikir kritis yang diakibatkan oleh penggunaan produk pembelajaran IPA yang dikembangkan. Hasil penelitian ini sesuai dengan penelitian sebelumnya yang dilakukan oleh (Sari, Saputro, \& Hastuti, 2014) yang menjelaskan bahwa penggunaan Game berbasis komputer yang dalam pembelajaran mempunyai efektivitas yang lebih baik daripada pembelajaran konvensional dalam hal penguasa- an konsep dan keterampilan berpikir kritis peserta didik.

Lewis-Harris (2010) menyatakan bahwa strategi yang digunakan untuk mengajar kemampuan berpikir kritis antara lain adalah higher order questioning, cooperative learning, enrichment, modeling, real-life applications, dan fostering affective domains. Pada penelitian ini yang digunakan untuk strategi tersebut antara lain adalah soal higher order questioning berupa soal berpikir kritis, active learning dengan membuat peserta didik belajar aktif secara mandiri, dan enrichment dengan menghadapkan peserta didik pada pemecahan masalah di kuis, materi dan memahami materi dengan audiovisual serta proses perpindahan kalor melalui animasi pada Game.

Kondisi tersebut sesuai dengan penelitian (Saptanningtyas \& Arifah, 2011), yang mengidentifikasi bahwa pembelajaran menggunakan game epsilon merupakan strategi alternatif untuk mengembangkan kemampuan berpikir kritis. Pembelajaran dengan menerapkan permainan epsilon memungkinkan peserta didik tidak hanya mendengar ceramah dari pendidik.

Kondisi tersebut sesuai dengan penelitian (Saptanningtyas \& Arifah, 2011), menginterpretasikan bahwa pembelajaran menggunakan Game merupakan strategi alternatif untuk mengembangkan kemampuan berpikir kritis. Pembelajaran dengan menerapkan permainan memungkinkan peserta didik tidak hanya duduk mendengar ceramah dari guru. Aktivitas dalam pembelajaran dengan metode ini memungkinkan peserta didik untuk mengembangkan kemampuan berfikir kritis mereka yaitu pada komponen problem solving dan evaluasi. Pembelajaran dengan menggunakan Game ini juga dapat menarik minat peserta didik karena aktivitas permainan yang menyenangkan. Rudiyanto (2010) menyimpulkan hal yang sama bahwa Game berbasis komputer dapat meningkatkan penguasaan konsep dan keterampilan berpikir kritis.

\section{SIMPULAN}

Sebuah studi telah dilakukan untuk mengembangkan media pembelajaran individu berupa game ritual tumpe. Berdasarkan temuan dan pembahasan, dapat disimpulkan bahwa: (1) media game yang dikembangkan pada materi suhu dan kalor dalam penelitian ini terbukti sangat valid oleh para ahli. Media sangat cocok untuk digunakan dalam proses pembelajaran IPA di SMP. Peserta didik memberikan respon positif terhadap pemanfaatan game ritual tumpe, dan 
implementasi pembelajaran dengan menggunakan game ritual tumpe dianggap sangat baik; (2) keterampilan berpikir kritis peserta didik kelas eksperimen sebelum dan setelah posttest mengalami perbedaan signifikan. Gain score yang diperoleh saat posttest adalah 0,67. Uji Manova dengan nilai sig. sebesar $0.000(<0.05)$. Kondisi tersebut menunjukkan bahwa media yang dikembangkan efektif dalam meningkatkan keterampilan berpikir kritis peserta didik SMP.

\section{DAFTAR PUSTAKA}

Bakan, U., \& Bakan, U. (2018). Game-based learning studies in education journals: A systematic review of recent trends. Actualidades Pedagógicas, (72), 119-145. https://doi.org/10.19052/ap.5245

Barzilai, S., \& Blau, I. (2014). Scaffolding gamebased learning: Impact on learning achievements, perceived learning, and game experiences. Computers \& Education, $\quad 70, \quad 65-79$. https://doi.org/10.1016/j.compedu.2013.0 8.003

Chang, C.-Y., Lai, C.-L., \& Hwang, G.-J. (2018). Trends and research issues of mobile learning studies in nursing education: A review of academic publications from 1971 to 2016. Computers \& Education, 116, 28-48. https://doi.org/10.1016/j.compedu.2017.0 9.001

Chee, Y. S., Tan, K. C. D., Tan, E. M., \& Jan, M. (2012). Learning chemistry performatively: Epistemological and pedagogical bases of design-for-learning with computer and video games. In Issues and Challenges in Science Education Research (pp. 245-262). Dordrecht: Springer Netherlands. https://doi.org/10.1007/978-94-007-39802_16

Cicchino, M. I. (2015). Using game-based learning to foster critical thinking in student discourse. Interdisciplinary Journal of Problem-Based Learning, 9(2). https://doi.org/10.7771/1541-5015.1481

Ennis, R. H. (1993). Critical thinking assessment. Theory Into Practice, 32(3), 179-186. https://doi.org/10.1080/004058493095435 94

Giannakos, M. N. (2013). Enjoy and learn with educational games: Examining factors affecting learning performance. Computers \& Education, 68, 429-439. https://doi.org/10.1016/j.compedu.2013.0 6.005

Gros, B. (2007). Digital games in education: The design of games-based learning environments. Journal of Research on Technology in Education, 40(1), 23-38. https://doi.org/10.1080/15391523.2007.10 782494

Hake, R. R. (1999). Analyzing change/Gain scores. Retrieved from http://www.physics.indiana.edu/ sdi/Anal yzingChange-Gain.pdf

Hao, H., Elvis, M., Civano, F., Lanzuisi, G., Brusa, M., Lusso, E., ... Vignali, C. (2010). Hot-dust-poor type 1 active galactic nuclei in the COSMOS survey. Astrophysical Journal Letters, 724(1 PART 2). https://doi.org/10.1088/20418205/724/1/L59

Hong, J.-C., Cheng, C.-L., Hwang, M.-Y., Lee, C.-K., \& Chang, H.-Y. (2009). Assessing the educational values of digital games. Journal of Computer Assisted Learning, 25(5), 423-437. https://doi.org/10.1111/j.13652729.2009.00319.x

Honiotes, J. (2011). Theories of thematic instruction. Retrieved from http://www.ehow.com/info_8552033_the ories-thematic-instruction.html

Kearsley, G. (2010). The theory into practice database.

Lewis-Harris, J. (2010). Personal reflection: A reflection on encouraging critical thinking and empathy: Using so-TL to examine teaching effectiveness in a social justice in graduate education class. International Journal for the Scholarship of Teaching and Learning, 4(1), n1.

Maddux, W. W., Adam, H., \& Galinsky, A. D. (2010). When in Rome ... Learn why the romans do what they do: How multicultural learning experiences facilitate creativity. Personality and Social Psychology Bulletin, 36(6), 731-741. https://doi.org/10.1177/014616721036778 6

Prasetyo, A. D. (2017). Pengembangan multimedia pembelajaran interaktif mata pelajaran IPA pokok bahasan bumi dan alam semesta kelas VI SD Negeri Ngringin 


\section{Jurnal Inovasi Pendidikan IPA, 5 (2), 2019 - 146}

Muliati Supandi, Senam Senam

Depok Sleman. E-Jurnal Skripsi Program Studi Teknologi Pendidikan, 6(7), 684697. Retrieved from http://journal.student.uny.ac.id/ojs/ojs/ind ex.php/fiptp/article/view/8410

Pusat Penelitian Pendidikan Kementerian Pendidikan dan Kebudayaan Republik Indonesia. (2019). Laporan hasil sekolah ujian nasional SMP/MTs.

Rini, R., Tangkas, I. M., \& Said, I. (2014). Meningkatkan hasil belajar siswa melalui penggunaan metode demonstrasi pada mata pelajaran IPA di kelas III SDN Inpres Tunggaling. Jurnal Kreatif Online, 2(1). Retrieved from http://jurnal.untad.ac.id/jurnal/index.php/J KTO/article/view/2987

Saptanningtyas, F. Y., \& Arifah, H. (2011). Learning using game: alternative strategy to develop critical thingking (Study casus on epsilon game in real analysis learning. In International Seminar and the Fourth National Conference on Mathematics Education 2011 "Building the Nation Character through Humanistic Mathematics Education" (pp. 1-9). Yogyakarta: Universitas Negeri Yogyakarta.

Sari, K. W., Saputro, S., \& Hastuti, B. (2014). Pengembangan game edukasi kimia berbasis role playing game (RPG) pada materi struktur atom sebagai media pembelajaran mandiri untuk siswa kelas $\mathrm{X}$ SMA di kabupaten Purworejo. Jurnal Pendidikan Kimia, 3(2), 96-104. Retrieved from http://www.jurnal.fkip.uns.ac.id/index.ph $\mathrm{p} /$ kimia/article/view/3717

Suastra, I. W. (2009). Pembelajaran sains terkini: Mendekatkan peserta didik dengan lingkungan alamiah dan sosial budayanya. Singaraja: Universitas Pendidikan Ganesha.

Sukardi. (2009). Metodologi penelitian pendidikan: kompetensi dan praktiknya. Jakarta: PT Bumi Aksara. https://doi.org/2009

Thiagarajan, S., Semmel, D. S., \& Semmel, M. I. (1974). Instructional development for training teachers of exceptional children: A sourcebook. Blomington: may be ordered from the Council for Exceptional Children.

Vlachopoulos, D., \& Makri, A. (2017). The effect of games and simulations on higher education: a systematic literature review. International Journal of Educational Technology in Higher Education, 14(1), 22. https://doi.org/10.1186/s41239-0170062-1 